\title{
Crystal Structure, Thermal Decomposition Mechanism and Properties of Lanthanide Supramolecular Complexes Based on 2,4,6-Trimethylbenzoic Acid and 5,5'-Dimethyl-2,2'-bipyridine
}

\author{
Mengxue Zhou ${ }^{1,2}$, Ning Ren ${ }^{3,{ }^{*}}$, Jianjun Zhang ${ }^{1,2,{ }^{*}}$ \\ ${ }^{1}$ Testing and Analysis Center, Hebei Normal University, Shijiazhuang 050024, China. \\ ${ }^{2}$ College of Chemistry \& Material Science, Hebei Normal University, Shijiazhuang 050024, China. \\ ${ }^{3}$ College of Chemical Engineering \& Material, Hebei Key Laboratory of Heterocyclic Compounds, Handan University, \\ Handan 056005, Hebei Province, China.
}

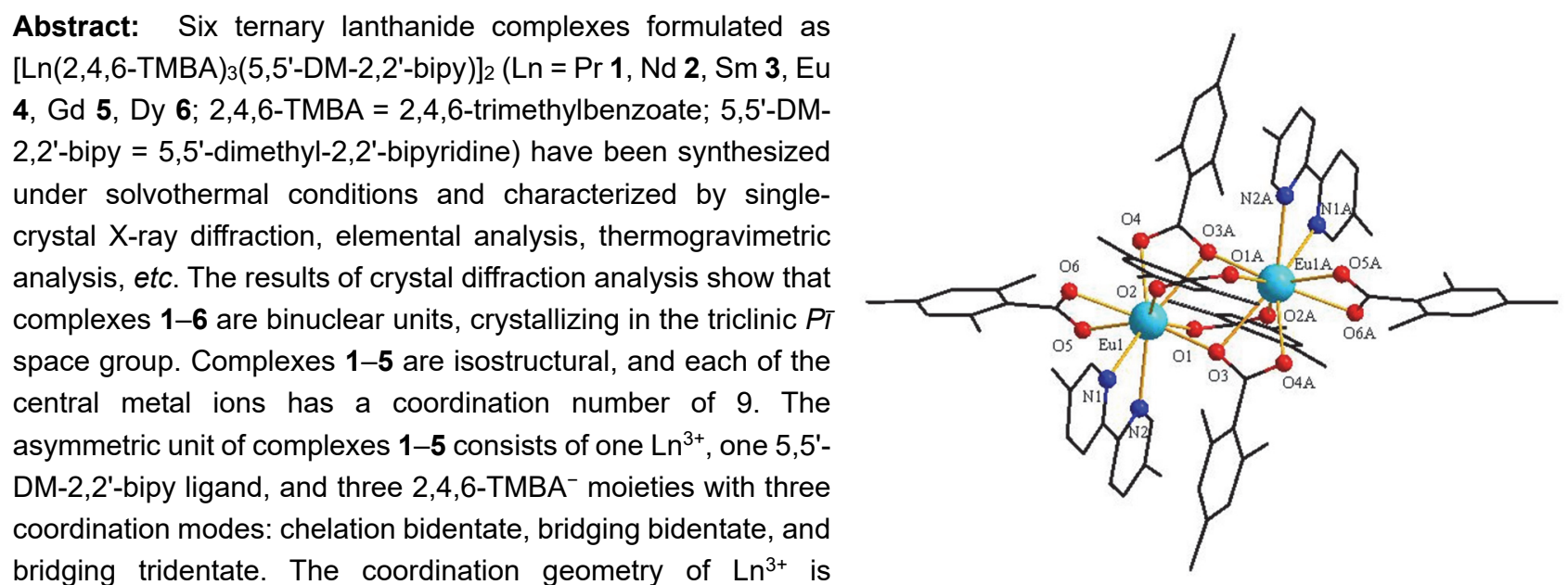
bridging tridentate. The coordination geometry of $\mathrm{Ln}^{3+}$ is distorted monocapped square antiprismatic. The binuclear units of complexes 1-5 form a one-dimensional (1D) supramolecular chain along the $c$-axis via $\pi-\pi$ stacking interactions between the 2,4,6-trimethylbenzoic acid rings. The 1D chains are linked to form a supramolecular two-dimensional (2D) sheet in the bc plane via $\pi-\pi$ stacking interactions between the pyridine rings. Although the molecular formulae of complex $\mathbf{6}$ and complexes 1-5 are similar, the coordination environment of the lanthanide ions is different in the two cases. The asymmetric unit of complex 6 contains a Dy ${ }^{3+}$ ion coordinated by a bidentate 5,5'-DM-2,2'-bipy and three 2,4,6-TMBA- ligands adopting bidentate and bridging bidentate coordination modes. The $\mathrm{Dy}^{3+}$ metal center has a coordination number of 8 , with distorted square antiprismatic molecular geometry. The binuclear molecule of 6 is assembled into a six-nuclear unit by $\pi-\pi$ weak staking interactions between two $5,5^{\prime}$-DM-2,2'-bipy ligands; then, adjacent six-nuclear units form a 1D chain via offset $\pi-\pi$ interactions between 5,5 '-DM2,2'-bipy ligands on different adjacent units. The adjacent $1 \mathrm{D}$ chains are linked by $\mathrm{C}-\mathrm{H} \cdots \mathrm{O}$ hydrogen bonding interactions to form a 2D supramolecular structure. The thermal stability and thermal decomposition mechanism of all the complexes are investigated by the combination of thermogravimetry and infrared spectroscopy (TG/FTIR) techniques under a simulated air atmosphere in the temperature range of $298-973 \mathrm{~K}$ at a heating rate of $10 \mathrm{~K} \cdot \mathrm{min}^{-1}$. Thermogravimetric studies show that this series of complexes have excellent thermal stability. During the thermal decomposition of the complex, the neutral ligand is lost first, followed by the acid ligand, and finally, the complex is decomposed into rare earth oxides. The three-dimensional infrared results are consistent with the thermogravimetric results. The photoluminescence spectra of complex 4 show the strong characteristic luminescence of $\mathrm{Eu}^{3+}$. The five typical emission peaks at 581, 591, 621, 651, and $701 \mathrm{~nm}$ correspond to the ${ }^{5} D_{0} \rightarrow{ }^{7} F_{0},{ }^{5} D_{0} \rightarrow{ }^{7} F_{1},{ }^{5} D_{0} \rightarrow{ }^{7} F_{2},{ }^{5} D_{0} \rightarrow{ }^{7} F_{3}$, and ${ }^{5} D_{0} \rightarrow{ }^{7} F_{4}$ electronic transitions of Eu ${ }^{3+}$, respectively. The emission at $621 \mathrm{~nm}$ is due to the electric dipole transition ${ }^{5} D_{0} \rightarrow{ }^{7} F_{2}$, while that at $591 \mathrm{~nm}$ is assigned to

Received: April 27, 2020; Revised: May 15, 2020; Accepted: May 15, 2020; Published online: May 20, 2020.

*Corresponding authors. Emails: jjzhang6@126.com (Z.J.); ningren9@163.com (R.N.). Tel.: +86-311-80786457 (Z.J.); +86-310-6260302 (R.N.).

The project was supported by the National Natural Science Foundation of China (21803016).

国家自然科学基金(21803016)资助项目

(C) Editorial office of Acta Physico-Chimica Sinica 
the ${ }^{5} D_{0} \rightarrow{ }^{7} F_{1}$ the magnetic dipole transition. The lifetime $(\tau)$ of complex 4 is calculated as $1.15 \mathrm{~ms}$ based on the equation $\left.T=\left(B_{1} T_{1}^{2}+B_{2} T_{2}^{2}\right)\right) /\left(B_{1} T_{1}+B_{2} T_{2}\right)$, and the intrinsic quantum yield is calculated to be $45.1 \%$. Further, the magnetic properties of complex 6 in the temperature range of $2-300 \mathrm{~K}$ are studied under an applied magnetic field of $1000 \mathrm{Oe}$.

Key Words: Lanthanide supramolecular complexes; Crystal structure, Thermal behavior; Luminescence spectrum; 2,4,6-Trimethylbenzoic acid

\title{
2,4,6-三甲基苯甲酸与 5,5'-二甲基-2,2'-联吡啶构筑的系列针系超分子 配合物的晶体结构、热分解机理和性能
}

\author{
周孟雪 1,2 , 任宁 $3,{ }^{*}$, 张建军 $1,2,{ }^{*}$ \\ 1 河北师范大学分析测试中心, 石家庄 050024 \\ 2 河北师范大学化学与材料科学学院, 石家庄 050024 \\ 3 邯弾学院, 化学化工与材料学院, 河北省杂环化合物重点实验室, 河北邯郸 056005
}

\begin{abstract}
摘要: 利用2,4,6-三甲基苯甲酸和5,5'-二甲基-2,2'-联吡啶配体在溶剂热的条件下成功合成出系列三元稀土超分子配合物 [Ln(2,4,6-TMBA $)_{3}\left(5,5^{\prime}-\mathrm{DM}-2,2^{\prime}-\right.$ bipy $\left.)\right]_{2}(\operatorname{Ln}=\operatorname{Pr} \mathbf{1}, \mathrm{Nd} \mathrm{2}, \mathrm{Sm}$ 3, Eu 4, Gd 5, Dy 6), 并对其进行了单晶X-射线衍射、元素 分析、热重分析等一系列表征。研究结果表明配合物1-5同构, 中心离子的配位数为 9 , 配合物通过 $\pi-\pi$ 堆积作用形成一 维、二维的超分子结构。配合物 6 具有不同的结构, 中心镝离子的配位数为 8 , 分子间通过 $\pi-\pi$ 堆积作用和 $\mathrm{C}-\mathrm{H} \cdots \mathrm{O}$ 氢 键形成一维、二维的超分子结构。利用TG/FTIR技术研究了配合物的热稳定性和热分解机理, 菼光光谱表明配合物 4 可以 发射出Eu $\mathrm{u}^{3+}$ 离子的特征荧光, 同时对配合物6的磁性进行了初步探究。
\end{abstract}

关键词：镧系超分子配合物; 晶体结构; 热分析; 苂光光谱; $2,4,6$-三甲基苯甲酸 中图分类号：0642

\section{Introduction}

Lanthanide complexes with various structures ${ }^{1}$ have attracted extensive attention due to their excellent optical ${ }^{2-5}$, magnetic ${ }^{6-9}$, adsorption 10 and catalytic properties ${ }^{11,12}$. Due to the particularity $4 f$ electron layer structure of lanthanides, lanthanide complexes have special luminescent properties such as high color purity, long decay times, high quantum yields, and so on ${ }^{13}$. These optical properties of lanthanide complexes have potential applications in fluorescent probes ${ }^{14}$ and luminescent bioassays ${ }^{15}$. However, $f-f$ transition is prohibited by spin and parity ${ }^{16}$, it is necessary to select appropriate organic chromophores to enhance the luminescence of intensity, which is called "antenna effect" ${ }^{17}$. Lanthanide has strong affinity with nitrogen or oxygen atoms, so aromatic carboxylic acids ligands: 3,4-diethoxybenzoic acid ${ }^{18}, 2,4$-dichlorobenzoic acid ${ }^{19}, 1,2,3,5$ benzenetetracarboxylic acid ${ }^{20}$, etc., and nitrogen-containing rigid ligands: 1,10-phenanthroline ${ }^{21}, 2,2^{\prime}$-bipyridine ${ }^{22}$, $2,2^{\prime}: 6^{\prime}, 2^{\prime \prime}$-terpyridine ${ }^{23}$, etc., are usually selected as ligand to synthesize lanthanide complexes. The introduction of nitrogencontaining second ligand can not only improve the stability of the complex, but also replace the position of the solvent, reduce energy loss and enhance luminous efficiency. The second ligand can also act as an energy donor, absorbing energy and transferring to the central ion, improving the luminous intensity. Deprotonated 2,4,6-trimethylbenzoic acid anions have multiple coordination modes, such as monodentate, bidentate, bridged bidentate, bridged tridentate, etc., providing a possibility for the diversity structure of lanthanide complexes. 2,4,6trimethylbenzoic acid as an aromatic carboxylic acid ligand combined with nitrogen-containing heterocyclic ligands 5,5'dimethyl-2,2'-bipyridine as antenna ligands sensitizes lanthanide ions and improves luminescence efficiency. In recent years, the thermal stability, decomposition mechanism and kinetics of complexes have been significantly increased ${ }^{24}$. TG/FTIR is usually used to monitor the mass loss in the process of gas escape and thermal decomposition at different temperatures, which provides valuable information for the structure of complexes. Moreover, the potential application of trivalent lanthanide ion coordination complexes in magnetic materials has attracted great attention 25 . Owing to the unquenched orbital angular momentum of high spin $4 f$ unpaired electrons in trivalent lanthanide ion, these lanthanide complexes show magnetic anisotropy ${ }^{26}$. Therefore lanthanide complexes are the most promising magnetic materials.

In this paper, we utilize 2,4,6-trimethylbenzoic acid and 5,5'dimethyl-2,2'-bipyridine to form six binuclear complexes, $\left[\operatorname{Ln}(2,4,6-T M B A)_{3}\left(5,5^{\prime}-\mathrm{DM}-2,2^{\prime} \text {-bipy }\right)\right]_{2}(\operatorname{Ln}=\operatorname{Pr} \mathbf{1}, \mathrm{Nd}$ 2, Sm 3, $\mathrm{Eu}$ 4, Gd 5, Dy 6). All the prepared complexes were characterized via single-crystal X-ray diffraction, elemental analysis etc. The pyrolysis mechanisms of the complexes were 
studied by the TG-DTG-DSC/FTIR technique. Solid state fluorescence and lifetime of complex 4 were studied. In addition, the magnetic property of $\mathbf{6}$ was also investigated.

\section{Experimental section}

\subsection{Materials and methods}

$\mathrm{Ln}\left(\mathrm{NO}_{3}\right)_{3} \cdot 6 \mathrm{H}_{2} \mathrm{O}(\mathrm{Ln}=\mathrm{Pr}, \mathrm{Nd}, \mathrm{Sm}, \mathrm{Eu}, \mathrm{Gd}, \mathrm{Dy})$ (Alfa Aesar, 99.9\%), 2,4,6-trimethylbenzoic acid (Alfa Aesar, 99\%), and 5,5'dimethyl-2,2'-bipyridine (Alfa Aesar, 98\%) were received from commercial suppliers and used as received without further purification. The Vario-EL II analyaer (Elementar, Germany) was used for elemental analyses $(\mathrm{C}, \mathrm{H}$ and $\mathrm{N})$ and the contents of lanthanide elements were titrated with ethylenediamine tetraacetic acid (EDTA). The TG-DTG/FTIR analyses were conducted in a simulated air atmosphere with the STA 449 F3 instrument (Netzsch, Germany) and the TENSOR 27 fourier transform infrared spectrometer (Bruker, Germany) at a heating rate of $10 \mathrm{~K} \cdot \mathrm{min}^{-1}$ with about 3-8 $\mathrm{mg}$ compounds. Excitation $\left(\lambda_{\mathrm{em}}=621 \mathrm{~nm}\right)$ and emission spectra $\left(\lambda_{\mathrm{ex}}=330 \mathrm{~nm}\right)$ and lifetimes of solid complexes were measured on a Fluorescence Spectrometer (Edinburgh Instruments Ltd., UK). In addition, magnetic susceptibilities of the complex 6 were performed on a MPMS XL-7 magnetometer (Quantum Design, USA) from $2 \mathrm{~K}$ to $300 \mathrm{~K}$ with an applied magnetic field of $1000 \mathrm{Oe}$.

\subsection{Synthesis of complexes 1-6}

Complexes 1-6 have the same synthetic conditions. A mixture of 2,4,6-trimethylbenzoic acid $(0.098 \mathrm{~g}, 0.60 \mathrm{mmol})$ and 5,5'dimethyl-2,2'-bipyridine $(0.037 \mathrm{~g}, 0.20 \mathrm{mmol})$ was dissolved in $6 \mathrm{~mL}$ ethanol solution with stirring. Adjust the $\mathrm{pH}$ value of the mixture to 5-7 with $1.0 \mathrm{~mol} \cdot \mathrm{L}^{-1} \mathrm{NaOH}$, add the mixture drop to $\mathrm{Ln}\left(\mathrm{NO}_{3}\right)_{3} \cdot 6 \mathrm{H}_{2} \mathrm{O}(0.20 \mathrm{mmol}, \mathrm{Ln}=\mathrm{Pr}, \mathrm{Nd}, \mathrm{Sm}, \mathrm{Eu}, \mathrm{Gd}, \mathrm{Dy})$ aqueous solution by stirring. After stirring for $40 \mathrm{~min}$, the suspension was sealed in a $25 \mathrm{~mL}$ Teflon-lined autoclave and heated to $120{ }^{\circ} \mathrm{C}$ for 7 days and then slowly cooled to room temperature, the crystals were collected by filtration, washed with ethanol and distilled water.

[Pr(2,4,6-TMBA)3(5,5'-DM-2,2'-bipy) ]2 (1), Elemental Anal. Calcd. for $\mathrm{C}_{84} \mathrm{H}_{90} \mathrm{~N}_{4} \mathrm{O}_{12} \mathrm{Pr}_{2}: \mathrm{C}, 61.96 ; \mathrm{H}, 5.61 ; \mathrm{N}, 3.42 ; \mathrm{Pr}, 17.35$, Found: C, 61.92; H, 5.57; N, 3.44; Pr, 17.30. [ $\mathrm{Nd}(2,4,6-$ TMBA $)_{3}(5,5 \text { '-DM-2,2'-bipy) }]_{2}$ (2), Elemental Anal. Calcd. for $\mathrm{C}_{84} \mathrm{H}_{90} \mathrm{~N}_{4} \mathrm{O}_{12} \mathrm{Nd}_{2}$ : C, 62.13; H, 5.61; N,3.49; Nd, 17.66, Found: C, 62.14; H, 5.54; N, 3.42; Nd, 17.63. [Sm(2,4,6-TMBA) $)_{3}(5,5$ 'DM-2,2'-bipy) $]_{2}$ (3), Elemental Anal. Calcd. for $\mathrm{C}_{84} \mathrm{H}_{90} \mathrm{~N}_{4} \mathrm{O}_{12} \mathrm{Sm}_{2}: \mathrm{C}, 61.23 ; \mathrm{H}, 5.49 ; \mathrm{N}, 3.44 ; \mathrm{Sm}, 18.25$, Found: C, 61.21; H, 5.50; N, 3.40; Sm, 18.24. [Eu(2,4,6-TMBA) $3(5,5$ 'DM-2,2'-bipy) $]_{2}$ (4), Elemental Anal. Calcd. for $\mathrm{C}_{84} \mathrm{H}_{90} \mathrm{~N}_{4} \mathrm{O}_{12} \mathrm{Eu}_{2}$ : C, 61.06; H, 5.52; N, 3.37; Eu, 18.45, Found: C, 61.09; H, 5.49; N, 3.39; Eu, 18.40. [Gd(2,4,6-TMBA) $3(5,5$ 'DM-2,2'-bipy) $]_{2}$ (5), Elemental Anal. Calcd. for $\mathrm{C}_{84} \mathrm{H}_{90} \mathrm{~N}_{4} \mathrm{O}_{12} \mathrm{Gd}_{2}$ : C, 60.73; H, 5.50; N, 3.36; Gd, 18.97, Found: C, 60.70; H, 5.46; N, 3.37; Gd, 18.92. [Dy(2,4,6-TMBA) $3(5,5$ 'DM-2,2'-bipy)]2 (6), Elemental Anal. Calcd. for $\mathrm{C}_{84} \mathrm{H}_{90} \mathrm{~N}_{4} \mathrm{O}_{12} \mathrm{Dy} 2$ : C, 60.30; H, 5.44; N, 3.39; Dy, 19.48; Found: C, 60.32; H, 5.42; N, 3.35; Dy, 19.43 .

\subsection{Single-crystal $X$-ray diffraction}

Crystallographic data for complexes 1-6 were collected on a Smart-1000 diffractometer (Bruker, Germany) using graphitemonochromated with Mo- $K_{\alpha}$ radiation $(\lambda=0.71073 \AA, 1 \AA=0.1$ $\mathrm{nm}$, the same below) at the temperature of $298 \mathrm{~K}$. Structures of complexes 1-6 were solved by means of direct methods and refined by full-matrix least-squares techniques on $F^{2}$ using the SHELXL-97 program. The detailed crystallographic data and

Table 1 Crystal data and structure refinement for complexes $1-6(1 \AA=0.1 \mathrm{~nm})$.

\begin{tabular}{|c|c|c|c|}
\hline Complex & 1 & 2 & 3 \\
\hline Empirical formula & $\mathrm{C}_{84} \mathrm{H}_{90} \mathrm{~N}_{4} \mathrm{O}_{12} \mathrm{Pr}_{2}$ & $\mathrm{C}_{84} \mathrm{H}_{90} \mathrm{~N}_{4} \mathrm{O}_{12} \mathrm{Nd}_{2}$ & $\mathrm{C}_{84} \mathrm{H}_{90} \mathrm{~N}_{4} \mathrm{O}_{12} \mathrm{Sm}_{2}$ \\
\hline Formula weight $/\left(\mathrm{g} \cdot \mathrm{mol}^{-1}\right)$ & 1629.42 & 1636.08 & 1648.30 \\
\hline Temperature/K & $298(2)$ & $298(2)$ & $298(2)$ \\
\hline Wavelength $/ \AA$ & 0.71073 & 0.71073 & 0.71073 \\
\hline Crystal system & Triclinic & Triclinic & Triclinic \\
\hline Space group & $P \overline{1}$ & $P \overline{1}$ & $P^{\overline{1}}$ \\
\hline \multicolumn{4}{|l|}{ Unit cell dimensions } \\
\hline$a / \AA$ & $12.4109(11)$ & $12.1605(13)$ & $12.3684(11)$ \\
\hline$b / \AA$ & $13.4486(12)$ & $13.1382(13)$ & $13.3244(11)$ \\
\hline$c / \AA$ & $13.4944(13)$ & $13.2316(14)$ & $13.4910(12)$ \\
\hline$\alpha /\left({ }^{\circ}\right)$ & $107.863(3)$ & $107.790(2)$ & $107.653(2)$ \\
\hline$\beta /\left({ }^{\circ}\right)$ & $108.458(3)$ & $108.686(2)$ & $108.945(2)$ \\
\hline$\gamma /\left(^{\circ}\right)$ & $91.858(2)$ & $91.7080(10)$ & $91.5490(10)$ \\
\hline Volume $/ \AA^{3}$ & $2012.4(3)$ & $1887.6(3)$ & $1984.4(3)$ \\
\hline$Z$, calculated density $/\left(\mathrm{mg} \cdot \mathrm{m}^{-3}\right)$ & $1,1.344$ & $1,1.439$ & $1,1.379$ \\
\hline Absorption coefficient $/ \mathrm{mm}^{-1}$ & 1.257 & 1.425 & 1.526 \\
\hline$F(000)$ & 836 & 838 & 842 \\
\hline Crystal size $/ \mathrm{mm}^{3}$ & $0.13 \times 0.08 \times 0.05$ & $0.16 \times 0.08 \times 0.06$ & $0.15 \times 0.08 \times 0.05$ \\
\hline
\end{tabular}




\begin{tabular}{|c|c|c|c|}
\hline Complex & 1 & 2 & 3 \\
\hline Theta range for data collection $/\left(^{\circ}\right)$ & 2.34 to 25.02 & 2.38 to 25.02 & 2.34 to 25.02 \\
\hline \multirow[t]{3}{*}{ Limiting indices } & $-14 \leq h \leq 14$ & $-14 \leq h \leq 14$ & $-14 \leq h \leq 14$ \\
\hline & $-15 \leq k \leq 15$ & $-11 \leq k \leq 15$ & $-15 \leq k \leq 15$ \\
\hline & $-12 \leq l \leq 16$ & $-15 \leq l \leq 15$ & $-10 \leq l \leq 16$ \\
\hline \multirow[t]{2}{*}{ Reflections collected/unique } & $10173 / 6956$ & $9719 / 6570$ & $10125 / 6888$ \\
\hline & {$[R($ int $)=0.0564]$} & {$[R($ int $)=0.0655]$} & {$[R(\mathrm{int})=0.0494]$} \\
\hline Completeness to theta $=25.02^{\circ}$ & $98.3 \%$ & $98.5 \%$ & $98.5 \%$ \\
\hline Max. and min. transmission & 0.9398 and 0.8537 & 0.9194 and 0.8041 & 0.9276 and 0.8034 \\
\hline Data/restraints/parameters & $6956 / 0 / 460$ & $6570 / 0 / 471$ & $6888 / 0 / 471$ \\
\hline Goodness-of-fit on $F^{2}$ & 1.072 & 1.033 & 1.014 \\
\hline \multirow[t]{2}{*}{ Final $R$ indices $[I>2 \sigma(I)]$} & $R_{1}=0.0681$ & $R_{1}=0.0650$ & $R_{1}=0.0533$ \\
\hline & $w R_{2}=0.1529$ & $w R_{2}=0.1490$ & $w R_{2}=0.0929$ \\
\hline \multirow[t]{2}{*}{$R$ indices (all data) } & $R_{1}=0.0929$ & $R_{1}=0.0901$ & $R_{1}=0.0832$ \\
\hline & $w R_{2}=0.1634$ & $w R_{2}=0.1621$ & $w R_{2}=0.1004$ \\
\hline Complex & 4 & 5 & 6 \\
\hline Empirical formula & $\mathrm{C}_{84} \mathrm{H}_{90} \mathrm{~N}_{4} \mathrm{O}_{12} \mathrm{Eu}_{2}$ & $\mathrm{C}_{84} \mathrm{H}_{90} \mathrm{~N}_{4} \mathrm{O}_{12} \mathrm{Gd}_{2}$ & $\mathrm{C}_{252} \mathrm{H}_{270} \mathrm{~N}_{12} \mathrm{O}_{36} \mathrm{Dy}_{6}$ \\
\hline Formula weight $/\left(\mathrm{g} \cdot \mathrm{mol}^{-1}\right)$ & 1651.52 & 1662.10 & 5017.80 \\
\hline Temperature/K & $298(2)$ & $298(2)$ & $298(2)$ \\
\hline Wavelength/ $/ \AA$ & 0.71073 & 0.71073 & 0.71073 \\
\hline Crystal system & Triclinic & Triclinic & Triclinic \\
\hline Space group & $P \overline{1}$ & $P \overline{1}$ & $P \overline{1}$ \\
\hline \multicolumn{4}{|l|}{ Unit cell dimensions } \\
\hline$a / \AA$ & $12.3030(11)$ & $11.8539(12)$ & $13.8471(12)$ \\
\hline$b / \AA$ & $13.1940(12)$ & $12.6869(13)$ & $16.3534(14)$ \\
\hline$c / \AA$ & $13.4110(12)$ & $12.9280(14)$ & $28.649(3)$ \\
\hline$\alpha /\left(^{\circ}\right)$ & $107.599(2)$ & $107.535(3)$ & $78.807(2)$ \\
\hline$\beta /\left(^{\circ}\right)$ & $109.113(4)$ & $109.358(3)$ & $77.3610(10)$ \\
\hline$\gamma /\left({ }^{\circ}\right)$ & $91.4870(10)$ & $91.3950(10)$ & $78.530(2)$ \\
\hline Volume $/ \AA^{3}$ & $1941.7(3)$ & $1732.3(3)$ & $6126.5(9)$ \\
\hline$Z$, calculated density $/\left(\mathrm{mg} \cdot \mathrm{m}^{-3}\right)$ & $1,1.412$ & $1,1.593$ & $1,1.360$ \\
\hline Absorption coefficient $/ \mathrm{mm}^{-1}$ & 1.663 & 1.968 & 1.875 \\
\hline$F(000)$ & 844 & 846 & 2550 \\
\hline Crystal size $/ \mathrm{mm}^{3}$ & $0.20 \times 0.11 \times 0.10$ & $0.11 \times 0.07 \times 0.04$ & $0.41 \times 0.37 \times 0.13$ \\
\hline Theta range for data collection $/\left(^{\circ}\right)$ & 2.36 to 25.02 & 2.67 to 25.02 & 2.30 to 25.02 \\
\hline \multirow[t]{3}{*}{ Limiting indices } & $-14 \leq h \leq 14$ & $-7 \leq h \leq 14$ & $-8 \leq h \leq 16$ \\
\hline & $-15 \leq k \leq 15$ & $-14 \leq k \leq 15$ & $-18 \leq k \leq 19$ \\
\hline & $-15 \leq l \leq 12$ & $-15 \leq l \leq 14$ & $-34 \leq l \leq 33$ \\
\hline \multirow[t]{2}{*}{ Reflections collected/unique } & $9927 / 6752$ & $8934 / 6028$ & $31411 / 21320$ \\
\hline & {$[R($ int $)=0.0280]$} & {$[R($ int $)=0.1072]$} & {$[R(\mathrm{int})=0.0620]$} \\
\hline Completeness to theta $=25.02^{\circ}$ & $98.5 \%$ & $98.9 \%$ & $98.5 \%$ \\
\hline Data/restraints/parameters & $6752 / 0 / 471$ & $6028 / 0 / 471$ & $21320 / 37 / 1378$ \\
\hline Goodness-of-fit on $F^{2}$ & 1.025 & 1.082 & 0.778 \\
\hline \multirow[t]{2}{*}{ Final $R$ indices $[I>2 \sigma(I)]$} & $R_{1}=0.0369$ & $R_{1}=0.0917$ & $R_{1}=0.0592$ \\
\hline & $w R_{2}=0.0688$ & $w R_{2}=0.2045$ & $w R_{2}=0.0973$ \\
\hline \multirow[t]{2}{*}{$R$ indices (all data) } & $R_{1}=0.0532$ & $R_{1}=0.1293$ & $R_{1}=0.1234$ \\
\hline & $w R_{2}=0.0744$ & $w R_{2}=0.2209$ & $w R_{2}=0.1125$ \\
\hline Largest diff. peak and hole $\left(e \cdot \AA^{-3}\right)$ & 1.858 and -0.644 & 2.959 and -2.296 & 2.028 and -0.891 \\
\hline Largest diff. peak and hole $\left(e \cdot \AA^{-3}\right)$ & 2.276 and -1.794 & 1.922 and -1.438 & 1.357 and -0.851 \\
\hline
\end{tabular}

$1 \AA=0.1 \mathrm{~nm}$, the same below.

structure refinements for all compounds are presented in Table 1.

\section{Results and discussion}

\subsection{Crystal structure description of complexes 1-6}

The results of crystal diffraction analysis show that although the molecular ratio of complexes $\mathbf{1 - 6}$ is the same, there are two different structures due to the contraction effect of lanthanide elements. Among them, complexes 1-5 are isostructural, the central ions are all nine-coordinated, while complex $\mathbf{6}$ is different with a coordination number of eight. So as a representative, the 
(a)

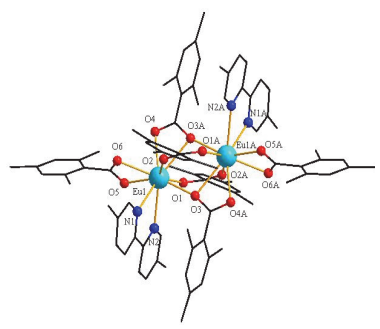

(b)

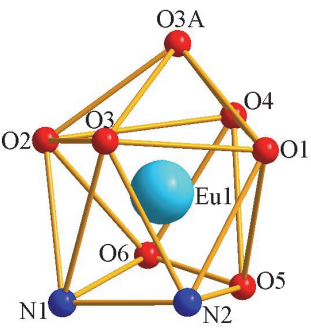

Fig. 1 (a) The molecular structure of complex 4; (b) coordination polyhedron of $\mathrm{Eu}^{3+}$ center.
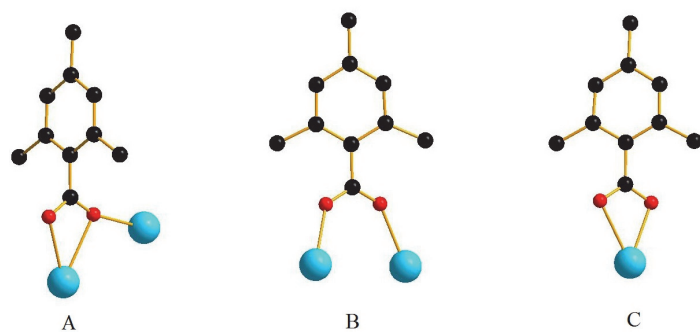

B

C

Fig. 2 Different coordination modes of 2,4,6-TMBA${ }^{-}$ligand for complex 4.

A: bridging tridentate, $\mathrm{B}$ : bridging bidentate, $\mathrm{C}$ : bidentate.

crystal structures of complexes $\mathbf{4}$ and $\mathbf{6}$ are employed to be discussed in detail.

\subsubsection{Crystal structure of $\left[\mathrm{Eu}(2,4,6-\mathrm{TMBA})_{3}\left(5,5^{\prime}-\mathrm{DM}\right.\right.$ -}

\section{$2,2^{\prime}$-bipy) $]_{2}$}

The complex 4 is a binuclear unit, crystallizing in the triclinic $P \overline{1}$ space group. As shown in Fig. 1a, the asymmetric unit of $\mathbf{4}$

consists of one $\mathrm{Eu}^{3+}$, one 5,5'-DM-2,2'-bipy ligand, three 2,4,6$\mathrm{TMBA}^{-}$with three coordination modes: chelation bidentate, bridging bidentate and bridging tridentate (Fig. 2). The $\mathrm{Eu}^{3+}$ is nine coordinated and displays a distorted monocapped square antiprismatic coordination geometry (Fig. 1b). In the polyhedron Eu1O $\mathrm{N}_{2}$, seven oxygen $(\mathrm{O} 1, \mathrm{O} 2, \mathrm{O} 3, \mathrm{O} 4, \mathrm{O} 3 \mathrm{~A}, \mathrm{O} 5$ and $\mathrm{O} 6)$ atoms are derived from 2,4,6-TMBA ${ }^{-}$ligand with different coordination modes, and two nitrogen $(\mathrm{N} 1, \mathrm{~N} 2)$ atoms are derived from the bidentate 5,5'-DM-2,2'-bipy ligand. The average bond distances of $\mathrm{Eu} 1-\mathrm{O}$ to $\mathrm{Eu} 1$ is $2.451 \AA$, while the bond distances of Eu1 $-\mathrm{N}$ (bound through N1, N2) is $2.653 \AA$. The Eu1 $-\mathrm{O}$ and Eu1 $-\mathrm{N}$ bond length ranges (Table 2) are similar to the bond lengths previously reported ${ }^{27}$.

As shown in Fig. 3a, the binuclear unit of $\mathbf{4}$ forms a onedimensional (1D) supramolecular chain along the $c$-axis via $\pi-\pi$ stacking interactions between 2,4,6-trimethylbenzoic acid rings with the distance of $3.726 \AA$. The 1D chain is linked to form a supramolecular two-dimensional (2D) sheet in about the $b c$ plane via $\pi-\pi$ stacking interactions between pyridine rings with the distance of $3.772 \AA$ (Fig. 3b).

\subsubsection{Crystal structure of $\mathrm{Dy}(2,4,6-\mathrm{TMBA})_{3}\left(5,5^{\prime}-\mathrm{DM}-2,2^{\prime}-\right.$ bipy)]2}

The complex 6 is also a binuclear molecule, crystallizing in the triclinic $P \overline{1}$ space group. Although the molecular formula of complex $\mathbf{6}$ and $\mathbf{4}$ are similar, the coordination environment of lanthanide ions is different. As shown in Fig. 4a, the asymmetric unit of complex 6 contains a $\mathrm{Dy}^{3+}$ coordinated by a bidentate

Table 2 The main bond lengths for complexes 1-6.

\begin{tabular}{|c|c|c|c|c|c|c|}
\hline & $\operatorname{Pr}(\mathbf{1})$ & Bond length $/ \AA$ & $\mathrm{Nd}(\mathbf{2}) \operatorname{Ln}-\mathrm{O} / \AA$ & Bond length $/ \AA$ & $\operatorname{Sm}(3)$ & Bond length $/ \AA ̊$ \\
\hline \multirow[t]{7}{*}{$\mathrm{Ln}-\mathrm{O}$} & $\operatorname{Pr}(1)-O(1)$ & 2.461 & $\mathrm{Nd}(1)^{-} \mathrm{O}(1)$ & 2.401 & $\mathrm{Sm}(1)-\mathrm{O}(1)$ & 2.396 \\
\hline & $\operatorname{Pr}(1)-O(2)$ & 2.581 & $\mathrm{Nd}(1)^{-} \mathrm{O}(2)$ & 2.515 & $\mathrm{Sm}(1)-\mathrm{O}(2) \# 1$ & 2.403 \\
\hline & $\operatorname{Pr}(1)-O(3)$ & 2.455 & $\mathrm{Nd}(1)^{-} \mathrm{O}(3)$ & 2.380 & $\mathrm{Sm}(1)-\mathrm{O}(3)$ & 2.366 \\
\hline & $\operatorname{Pr}(1)-O(4) \# 1$ & 2.458 & $\mathrm{Nd}(1)^{-} \mathrm{O}(4) \# 1$ & 2.383 & $\operatorname{Sm}(1)-O(4) \# 1$ & 2.574 \\
\hline & $\operatorname{Pr}(1)-O(5)$ & 2.440 & $\mathrm{Nd}(1)-\mathrm{O}(5)$ & 2.374 & $\mathrm{Sm}(1)-\mathrm{O}(5)$ & 2.402 \\
\hline & $\operatorname{Pr}(1)-O(6) \# 1$ & 2.617 & $\mathrm{Nd}(1)-\mathrm{O}(6) \# 1$ & 2.557 & $\operatorname{Sm}(1)-O(6)$ & 2.528 \\
\hline & $\operatorname{Pr}(1)-O(5) \# 1$ & 2.702 & $\mathrm{Nd}(1)-\mathrm{O}(5) \# 1$ & 2.633 & $\mathrm{Sm}(1)-\mathrm{O}(3) \# 1$ & 2.666 \\
\hline Average $\mathrm{Ln}-\mathrm{O}$ & & 2.531 & & 2.463 & & 2.476 \\
\hline \multirow[t]{2}{*}{$\mathrm{Ln}-\mathrm{N}$} & $\operatorname{Pr}(1)-N(1)$ & 2.722 & $\mathrm{Nd}(1)-\mathrm{N}(1)$ & 2.646 & $\operatorname{Sm}(1)-N(1)$ & 2.677 \\
\hline & $\operatorname{Pr}(1)-N(2)$ & 2.737 & $\mathrm{Nd}(1)-\mathrm{N}(2)$ & 2.678 & $\operatorname{Sm}(1)-\mathrm{N}(2)$ & 2.694 \\
\hline \multirow[t]{2}{*}{ Average $\mathrm{Ln}-\mathrm{N}$} & & 2.730 & & 2.662 & & 2.686 \\
\hline & $\mathrm{Eu}(4)$ & Bond length/Å & $\operatorname{Gd}(\mathbf{5})$ & Bond length/Å & $\operatorname{Dy}(6)$ & Bond length $/ \AA$ \\
\hline \multirow[t]{7}{*}{$\mathrm{Ln}-\mathrm{O}$} & $\mathrm{Eu}(1)-\mathrm{O}(1)$ & 2.367 & $\mathrm{Gd}(1)-\mathrm{O}(1)$ & 2.271 & $\mathrm{Dy}(1)-\mathrm{O}(1)$ & 2.394 \\
\hline & $\mathrm{Eu}(1)-\mathrm{O}(2) \# 1$ & 2.372 & $\mathrm{Gd}(1)-\mathrm{O}(2) \# 1$ & 2.288 & $\mathrm{Dy}(1)-\mathrm{O}(3)$ & 2.274 \\
\hline & $\mathrm{Eu}(1)-\mathrm{O}(3)$ & 2.346 & $\mathrm{Gd}(1)-\mathrm{O}(3)$ & 2.246 & $\mathrm{Dy}(1)-\mathrm{O}(5)$ & 2.374 \\
\hline & $\mathrm{Eu}(1)-\mathrm{O}(4) \# 1$ & 2.535 & $\mathrm{Gd}(1)-\mathrm{O}(4) \# 1$ & 2.417 & $\mathrm{Dy}(1)-\mathrm{O}(7)$ & 2.326 \\
\hline & $\mathrm{Eu}(1)-\mathrm{O}(5)$ & 2.381 & $\mathrm{Gd}(1)-\mathrm{O}(5)$ & 2.276 & $\mathrm{Dy}(1)-\mathrm{O}(9)$ & 2.409 \\
\hline & $\mathrm{Eu}(1)-\mathrm{O}(6)$ & 2.503 & $\mathrm{Gd}(1)-\mathrm{O}(6)$ & 2.413 & $\mathrm{Dy}(1)-\mathrm{O}(10)$ & 2.461 \\
\hline & $\mathrm{Eu}(1)-\mathrm{O}(3) \# 1$ & 2.651 & $\mathrm{Gd}(1)-\mathrm{O}(3) \# 1$ & 2.566 & & \\
\hline Average $\mathrm{Ln}-\mathrm{O}$ & & 2.451 & & 2.354 & & 2.373 \\
\hline \multirow[t]{2}{*}{$\mathrm{Ln}-\mathrm{N}$} & $\mathrm{Eu}(1)-\mathrm{N}(1)$ & 2.637 & $\mathrm{Gd}(1)-\mathrm{N}(1)$ & 2.501 & $\operatorname{Dy}(1)-\mathrm{N}(1)$ & 2.565 \\
\hline & $\mathrm{Eu}(1)-\mathrm{N}(2)$ & 2.668 & $\mathrm{Gd}(1)-\mathrm{N}(2)$ & 2.571 & $\operatorname{Dy}(1)-\mathrm{N}(2)$ & 2.588 \\
\hline Average $\mathrm{Ln}-\mathrm{N}$ & & 2.653 & & 2.536 & & 2.577 \\
\hline
\end{tabular}




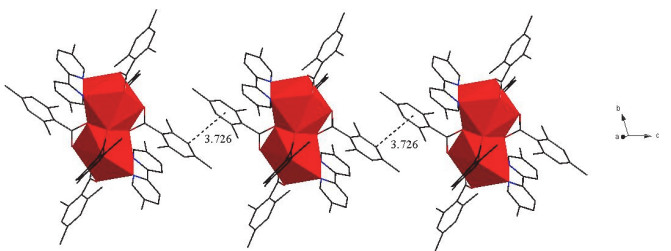

(a)

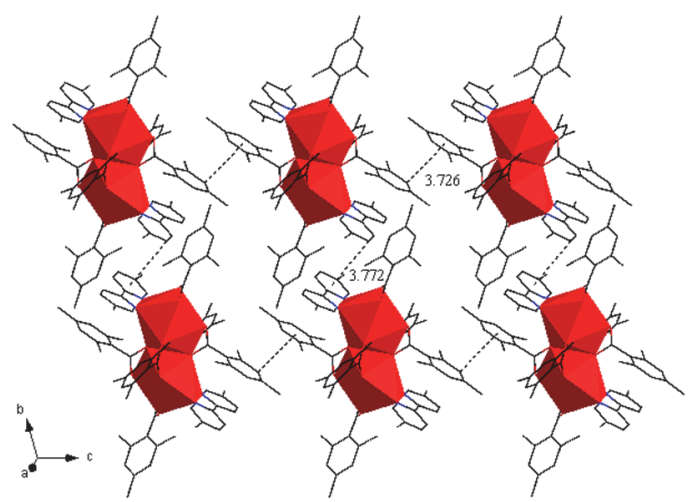

(b)

Fig. 3 (a) The supramolecular 1D chain structure of 4 along the $c$ axis; (b) The supramolecular 2D sheet of 4 in about the $b c$ plane.

(a)

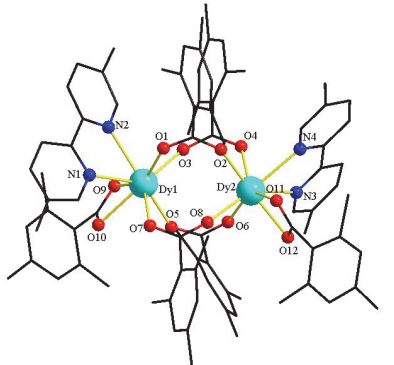

(b)

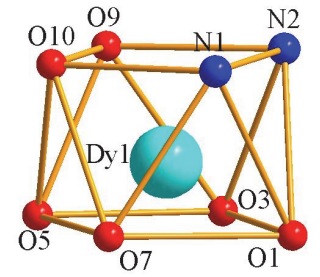

Fig. 4 (a) The molecular structure of complex 6; (b) Coordination polyhedron of $\mathrm{Dy}^{3+}$ center.

5,5'-DM-2,2'-bipy and three 2,4,6-TMBA ${ }^{-}$ligand adopting bidentate and bridging bidentate coordination modes. The $\mathrm{Dy}^{3+}$ metal center has a coordination number of eight with a distorted square antiprismatic molecular geometry (Fig. 4b). Dy1-O bond distances for the bidentate 2,4,6-TMBA ${ }^{-}$ligand (O9 and O10) are $2.409 \AA$ and $2.461 \AA$. Dy1-O bond distances for the bridging bidentate 2,4,6-TMBA ${ }^{-}$ligand (O1, O3, O5 and O7) are $2.394 \AA, 2.274 \AA, 2.374 \AA$ and $2.326 \AA$, respectively. The Dy $1-\mathrm{N} 1$ and Dy1 $-\mathrm{N} 2$ bond distances are $2.565 \AA$ and 2.588 $\AA$. The $\mathrm{Ln}-\mathrm{O}, \mathrm{Ln}-\mathrm{N}$ distances and their average distances for complexes 1-6 are listed in Table 2. Obviously, the shrinkage effect of lanthanides is reflected in the decrease of average Ln$\mathrm{O}$ bond length and average $\mathrm{Ln}-\mathrm{N}$ bond length with the increase of atomic number ${ }^{28}$.

Although both complex 6 and complex 4 are binuclear molecules with similar molecular ratios, the coordination numbers of the central rare earth ions are different, furthermore, the $1 \mathrm{D}$ and $2 \mathrm{D}$ supramolecular structures are quite different. The binuclear molecule of $\mathbf{6}$ is assembled into a six-nuclear units by $\pi-\pi$ weak staking interactions between two $5,5^{\prime}$-DM-2,2'-bipy ligands with the distance of $3.752 \AA$, then adjacent six-nuclear units via offset $\pi-\pi$ interactions between 5,5'-DM-2,2'-bipy ligands on different adjacent units forms a 1D chain, where the distance is $3.614 \AA$ (Fig. 5a). The adjacent 1D chains are linked by $\mathrm{C}-\mathrm{H} \cdots \mathrm{O}$ hydrogen bonding interactions with the distance of $3.456 \AA$ to construct two-dimensional supramolecular structure (Fig. 5b).

\subsection{Thermal analysis}

To investigate the pyrolytic dissociation mechanism and thermal stability of ternary lanthanide complexes, we measured the thermal behavior using TG-DTG-DSC under a simulated air atmosphere in the temperature range of $298-973 \mathrm{~K}$ with a heating rate of $10 \mathrm{~K} \cdot \mathrm{min}^{-1}$. Thermal analysis curves of $\mathbf{1}-\mathbf{6}$ are shown in Fig. S1(a-f) (in Supporting Information). The details of the pyrolysis steps (mass losses, temperature ranges, probable expelled groups and peak temperatures of DTG) are exhibited in Table 3. The complexes $\mathbf{1}-\mathbf{5}$ have the similar pyrolysis steps, the complex 4 as a representative will be discussed in detail.

The thermal decomposition temperature of complex $\mathbf{4}$ is $454.15 \mathrm{~K}$, which has certain thermal stability. The first mass loss between $454.15-547.15 \mathrm{~K}$, is connected with symmetry peak on DTG curves centered at $497.25 \mathrm{~K}$ (experiment value of mass loss $=22.16 \%$, calculated value of mass loss $=22.31 \%$ ). The mass loss percent is close to the theoretical value of two 5,5'-DM-2,2'dipy losses. Additionally, in the DSC curves of complex 4, a low endothermic peak is observed. Over $547.15 \mathrm{~K}$, the DTG curve of complex 4 shows that the mass loss is divided into three overlapping steps. The first one is centered at $615.85 \mathrm{~K}$ with mass loss of $26.76 \%$. The second one is centered at $658.95 \mathrm{~K}$ with mass loss of $5.65 \%$. The third one is centered at $710.45 \mathrm{~K}$ with mass loss of $23.86 \%$. These steps are corresponding to the loss of six 2,4,6-TMBA ligands (experiment value of mass loss = $56.27 \%$, calculated value of mass loss $=56.38 \%$ ). In the meantime, three exothermic peaks on the DSC curve can be

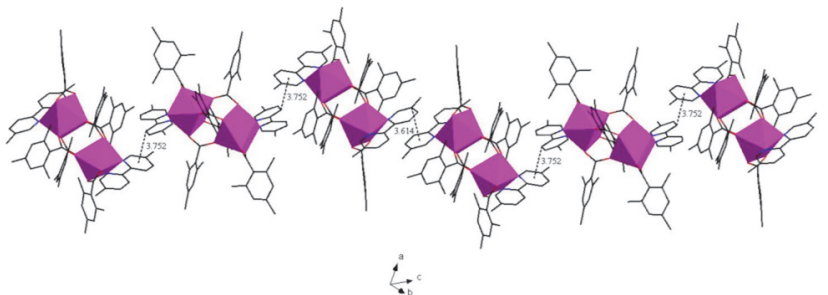

(a)

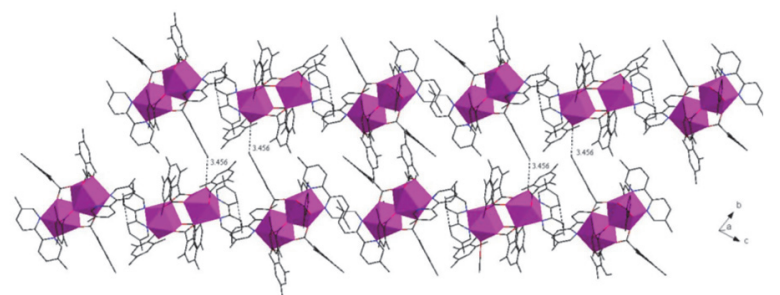

(b)

Fig. 5 (a) Supramolecular 1D chain in 6 along the $c$ axis; (b) Supramolecular 2D sheet in 6 about the $b c$ plane. 
物理化学学报 Acta Phys. -Chim. Sin. 2021, 37 (10), 2004071 (7 of 10)

Table 3 Thermal data for the complexes 1-6 at pressure $101.3 \mathrm{kPa}$.

\begin{tabular}{|c|c|c|c|c|c|c|c|}
\hline & \multirow{2}{*}{ Step } & \multirow{2}{*}{ Temperature range/K } & \multirow{2}{*}{ DTG $T_{\mathrm{p}} / \mathrm{K}$} & \multicolumn{2}{|c|}{ Mass loss rate $/ \%$} & \multirow{2}{*}{ Probable expelled groups } & \multirow{2}{*}{ Intermediate and residue } \\
\hline & & & & Found & Calcd. & & \\
\hline \multirow[t]{5}{*}{1} & I & $454.15-555.15$ & 512.95 & 22.59 & $22.61^{\mathrm{a}}$ & 2(5,5'-DM-2,2'-dipy) & {$\left[\mathrm{Pr}_{2}(2,4,6-\mathrm{TMBA})_{6}\right]$} \\
\hline & II & $555.15-678.15$ & 630.05 & 32.20 & & $x 2,4,6-\mathrm{TMBA}$ & {$\left[\operatorname{Pr}_{2}(2,4,6-\mathrm{TMBA})_{6-x}\right]$} \\
\hline & III & $678.15-716.15$ & 690.95 & 4.50 & & $y 2,4,6-\mathrm{TMBA}$ & {$\left[\operatorname{Pr}_{2}(2,4,6-\mathrm{TMBA})_{6-x-y}\right]$} \\
\hline & IV & $716.15-873.15$ & 761.35 & 19.80 & $56.49^{b}$ & $(6-x-y)$ 2,4,6-TMBA & $\mathrm{Pr}_{6} \mathrm{O}_{11}$ \\
\hline & & & & 79.09 & $79.10^{\mathrm{c}}$ & & \\
\hline \multirow[t]{5}{*}{2} & I & $457.15-554.15$ & 507.35 & 22.22 & $22.52^{\mathrm{a}}$ & 2(5,5'-DM-2,2'-dipy) & {$\left[\mathrm{Nd}_{2}(2,4,6-\mathrm{TMBA})_{6}\right]$} \\
\hline & II & $554.15-681.15$ & 633.35 & 32.28 & & $x$ 2,4,6-TMBA & {$\left[\mathrm{Nd}_{2}(2,4,6-\mathrm{TMBA})_{6-x}\right]$} \\
\hline & III & $681.15-716.15$ & 689.75 & 4.78 & & у $2,4,6-\mathrm{TMBA}$ & {$\left[\mathrm{Nd}_{2}(2,4,6-\mathrm{TMBA})_{6-x-y}\right]$} \\
\hline & IV & $716.15-973.15$ & 752.85 & 18.91 & $56.91^{\mathrm{b}}$ & $(6-x-y)$ 2,4,6-TMBA & $\mathrm{Nd}_{2} \mathrm{O}_{3}$ \\
\hline & & & & 78.19 & $79.43^{\mathrm{c}}$ & & \\
\hline \multirow[t]{5}{*}{3} & I & $455.15-548.15$ & 496.45 & 22.26 & $22.35^{\mathrm{a}}$ & 2(5,5'-DM-2,2'-dipy) & {$\left[\mathrm{Sm}_{2}(2,4,6-\mathrm{TMBA})_{6}\right]$} \\
\hline & II & $548.15-682.15$ & 632.45 & 33.07 & & $x 2,4,6-\mathrm{TMBA}$ & {$\left[\mathrm{Sm}_{2}(2,4,6-\mathrm{TMBA})_{6-x}\right]$} \\
\hline & III & $682.15-731.15$ & 691.85 & 8.21 & & $y 2,4,6-\mathrm{TMBA}$ & {$\left[\mathrm{Sm}_{2}(2,4,6-\mathrm{TMBA})_{6-x-y}\right]$} \\
\hline & IV & $731.15-973.15$ & 763.25 & 15.19 & $56.49^{\mathrm{b}}$ & $(6-x-y) 2,4,6-\mathrm{TMBA}$ & $\mathrm{Sm}_{2} \mathrm{O}_{3}$ \\
\hline & & & & 78.73 & $78.84^{\mathrm{c}}$ & & \\
\hline \multirow[t]{5}{*}{4} & I & $456.15-547.15$ & 497.25 & 22.16 & $22.31^{\mathrm{a}}$ & 2(5,5'-DM-2,2'-dipy) & {$\left[\mathrm{Eu}_{2}(2,4,6-\mathrm{TMBA})_{6}\right]$} \\
\hline & II & $547.15-647.15$ & 615.85 & 26.76 & & $x 2,4,6-\mathrm{TMBA}$ & {$\left[\mathrm{Eu}_{2}(2,4,6-\mathrm{TMBA})_{6-x}\right]$} \\
\hline & III & $647.15-675.15$ & 658.95 & 5.65 & & y 2,4,6-TMBA & {$\left[\mathrm{Eu}_{2}(2,4,6-\mathrm{TMBA})_{6-x-y}\right]$} \\
\hline & IV & $675.15-973.15$ & 710.45 & 23.86 & $56.38^{\mathrm{b}}$ & $(6-x-y) 2,4,6-\mathrm{TMBA}$ & $\mathrm{Eu}_{2} \mathrm{O}_{3}$ \\
\hline & & & & 78.43 & $78.69^{\mathrm{c}}$ & & \\
\hline \multirow[t]{5}{*}{5} & I & $454.15-548.15$ & 485.15 & 22.11 & $22.12^{\mathrm{a}}$ & 2(5,5'-DM-2,2'-dipy) & {$\left[\mathrm{Gd}_{2}(2,4,6-\mathrm{TMBA})_{6}\right]$} \\
\hline & II & $548.15-682.15$ & 633.45 & 32.11 & & $x 2,4,6-\mathrm{TMBA}$ & {$\left[\mathrm{Gd}_{2}(2,4,6-\mathrm{TMBA})_{6-x}\right]$} \\
\hline & III & $682.15-737.15$ & 693.05 & 9.39 & & $y 2,4,6-\mathrm{TMBA}$ & {$\left[\mathrm{Gd}_{2}(2,4,6-\mathrm{TMBA})_{6-x-y}\right]$} \\
\hline & IV & $737.15-973.15$ & 764.25 & 14.10 & $56.11^{\mathrm{b}}$ & $(6-x-y)$ 2,4,6-TMBA & $\mathrm{Gd}_{2} \mathrm{O}_{3}$ \\
\hline & & & & 77.71 & $78.23^{\mathrm{c}}$ & & \\
\hline \multirow[t]{6}{*}{6} & I & $432.15-460.15$ & 456.85 & 5.15 & & $x\left(5,5^{\prime}\right.$-DM-2,2'-dipy) & {$\left[\mathrm{Dy}_{2}(2,4,6-\mathrm{TMBA})_{6}\left(5,5^{\prime}-\mathrm{DM}-2,2^{\prime}-\mathrm{dipy}\right)_{2-x}\right]$} \\
\hline & II & $460.15-540.15$ & 469.25 & 16.95 & $22.03^{\mathrm{a}}$ & $2-x\left(5,5^{\prime}-\mathrm{DM}-2,2^{\prime}\right.$-dipy $)$ & {$\left[\mathrm{Dy}_{2}(2,4,6-\mathrm{TMBA})_{6}\right]$} \\
\hline & III & $540.15-687.15$ & 621.25 & 29.97 & & $y 2,4,6-\mathrm{TMBA}$ & {$\left[\mathrm{Dy}_{2}(2,4,6-\mathrm{TMBA})_{6-y}\right]$} \\
\hline & IV & $687.15-736.15$ & 702.45 & 8.22 & & $z$ 2,4,6-TMBA & {$\left[\mathrm{Dy}_{2}(2,4,6-\mathrm{TMBA})_{6-y-z}\right]$} \\
\hline & $\mathrm{V}$ & $736.15-873.15$ & 763.85 & 15.99 & $55.67^{\mathrm{b}}$ & $(6-y-z) 2,4,6-\mathrm{TMBA}$ & $\mathrm{Dy}_{2} \mathrm{O}_{3}$ \\
\hline & & & & 76.28 & $77.70^{\mathrm{c}}$ & & \\
\hline
\end{tabular}

${ }^{\mathrm{a}}$ Theoretical total mass loss of two $5,5^{\prime}$-DM-2,2'-bipy; ${ }^{\mathrm{b}}$ Theoretical total mass loss of six 2,4,6-TMBA; ${ }^{\mathrm{c}}$ The total loss rate.

found. Complex 4 was eventually completely collapsed into $\mathrm{Eu}_{2} \mathrm{O}_{3}$.

The decomposition temperature of complex 6 is $432.15 \mathrm{~K}$. In the range of $432.15-540.15 \mathrm{~K}$, the DTG curve of complex 6 shows the mass loss in the two overlapping steps. The first one is centered at $456.85 \mathrm{~K}$ with mass loss of $5.15 \%$. The second one is centered at $469.25 \mathrm{~K}$ with mass loss of $16.95 \%$. The DSC curve has no obvious endothermic peak in this temperature range. Between 540.15-873.15 K, the DTG curve for complex 6 shows mass losses in three overlapping steps, they are centered at $621.25,702.45$ and $763.85 \mathrm{~K}$ and corresponds to mass loss of $29.97 \%, 8.22 \%$ and $15.99 \%$, respectively. Compared with complexes 1-5, the exothermic peak on the DSC curve of complex 6 is significantly lower at $540.15-873.15 \mathrm{~K}$. Complex 6 was eventually completely collapsed into $\mathrm{Dy}_{2} \mathrm{O}_{3}$.

\subsection{Evolved gas analysis}

In order to further study the pyrolysis behavior of complexes, the TG/FTIR spectra were obtained by thermogravimetry followed by Fourier transform infrared spectroscopy system. The 3D stacked plots of the FTIR spectra are presented in Fig. 6a-f and the 2D IR spectra are shown in Fig. 7a-f. We take complex $\mathbf{4}$ as an example to give a detailed explanation. It can be seen from Fig. $7 \mathrm{~d}$ that there are four infrared absorption peaks at different temperatures ( $T=500.44,616.48,653.26,710.44 \mathrm{~K})$, which are consistent with the strongest absorption peaks of gases escaping from four temperature ranges (456.15-547.15, 547.15$647.15,647.15-675.15,675.15-973.15 \mathrm{~K})$. In the first stage, at $500.44 \mathrm{~K}$, the characteristic signal of $v_{\mathrm{C}=\mathrm{C}}$ at 1469 and 1600 $\mathrm{cm}^{-1}, v_{\mathrm{C}=\mathrm{N}}$ at $1558 \mathrm{~cm}^{-1}, v_{\mathrm{C}-\mathrm{N}}$ at 1130 and $1218 \mathrm{~cm}^{-1}, v_{\mathrm{C}-\mathrm{H}}$ at 2881-3036 $\mathrm{cm}^{-1}, \gamma_{\mathrm{C}-\mathrm{H}}$ at 826,1029 and $1061 \mathrm{~cm}^{-1}$ were observed. This indicates the loss of the neutral ligands in the first step. In the second IR spectrum at $616.48 \mathrm{~K}$, the sharp absorption peak at $1797 \mathrm{~cm}^{-1}$ is $v_{\mathrm{C}=\mathrm{O}}$ from the carboxylic acid group, and the absorption peak in the region between $2258-2360 \mathrm{~cm}^{-1}$ and $669 \mathrm{~cm}^{-1}$ were attributed to the absorption peak of $\mathrm{CO}_{2}$. The absorption peaks of $v_{\mathrm{C}-\mathrm{H}}$ at $2889-3025 \mathrm{~cm}^{-1}, \delta_{\mathrm{C}-\mathrm{H}}$ at 849 and 


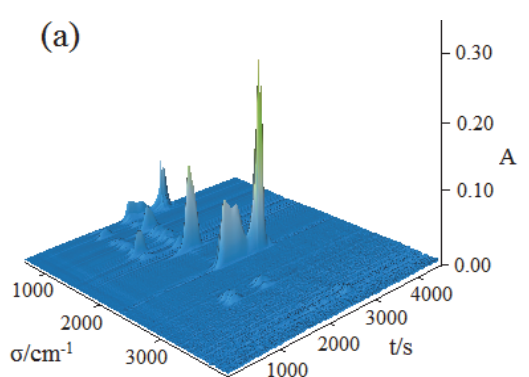

(d)

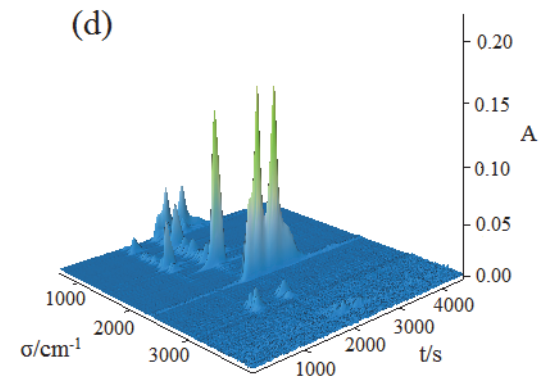

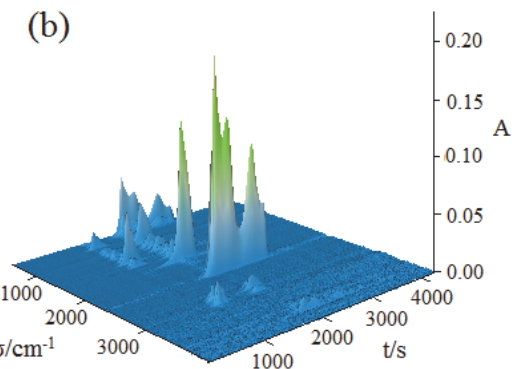

(e)

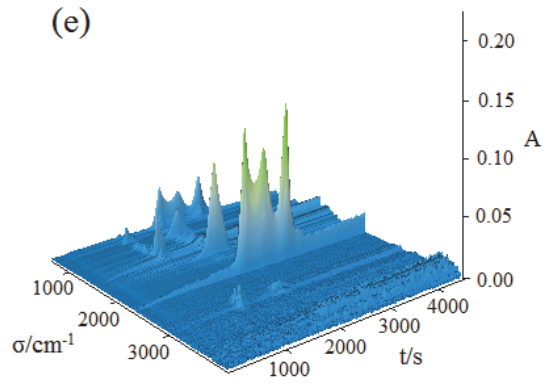

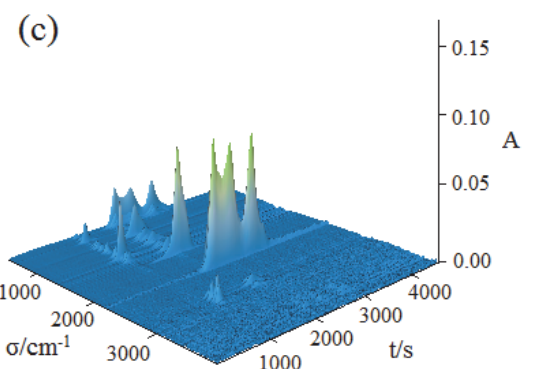

(f)

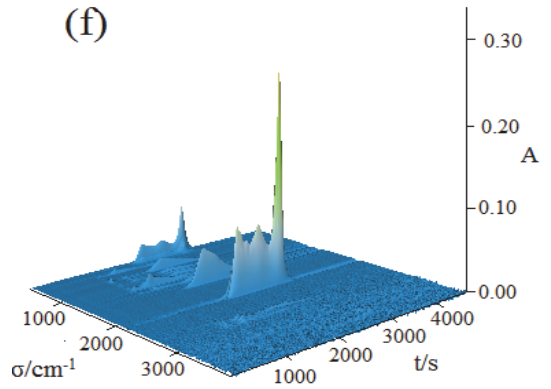

Fig. 6 The 3D IR image of the gas escaping from the complexes 1-6 (a-f) during pyrolysis.

(a)

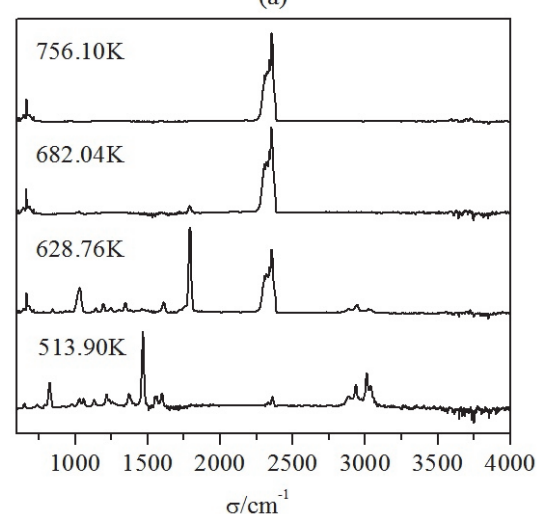

(d)

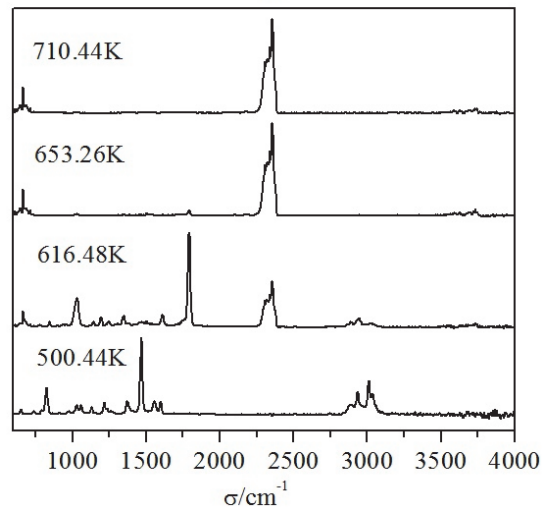

(b)

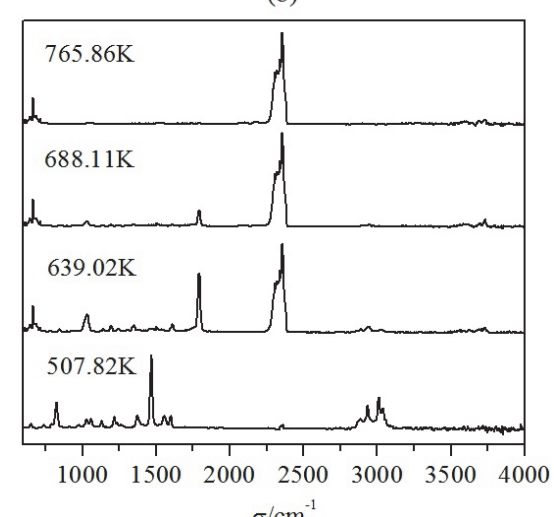

(e)

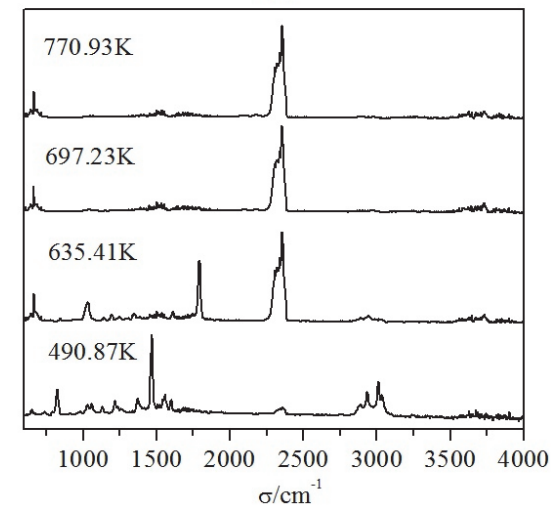

(c)

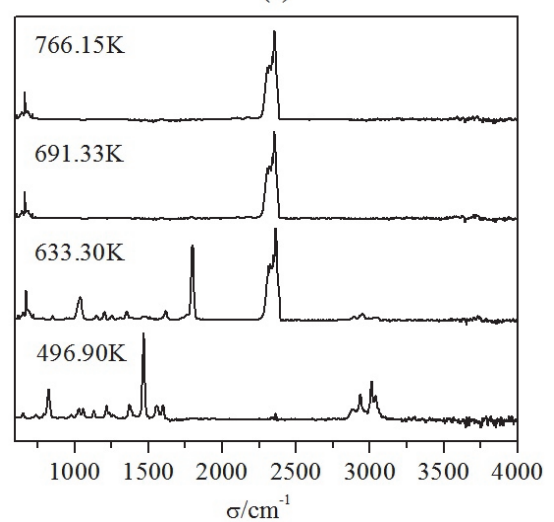

(f)

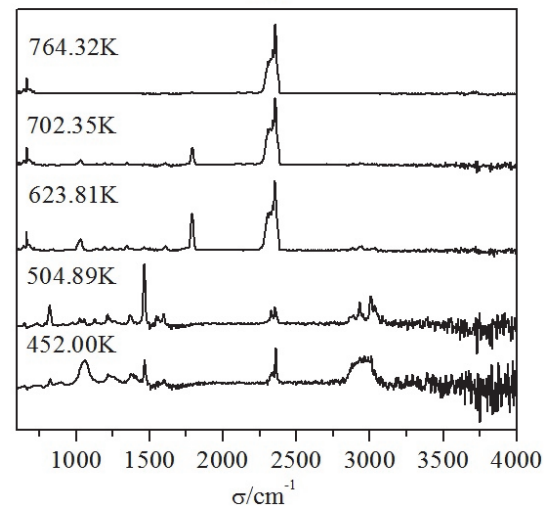

Fig. 7 The 2D IR spectra of the gaseous mixtures for complexes 1-6 (a-f).

$1036 \mathrm{~cm}^{-1}, v_{\mathrm{C}=\mathrm{C}}$ at $1615 \mathrm{~cm}^{-1}$, and weak water peak at 3600 $3800 \mathrm{~cm}^{-1}$ was observed, The results were consistent with the loss of the aromatic carboxylic acid ligand in the second step of the thermogravimetric analysis. In the infrared spectrum of the third and fourth steps, only the strong absorption peak of $\mathrm{CO}_{2}$ at $2258-2360 \mathrm{~cm}^{-1}$ and $669 \mathrm{~cm}^{-1}$ and the weak water peak at 3600 $3800 \mathrm{~cm}^{-1}$ were left on the infrared spectrum. This indicates that the carboxylic acid ligands have been completely cleaved.
For complex 6, the formation of complex can be divided into five steps according to the 3D IR spectrum of evolved gas. The five IR spectra at different temperatures $(T=452.00,504.89$, 623.81, 702.35 and $764.32 \mathrm{~K}$ ) were shown in Fig. 7f. At 452.00 and $504.89 \mathrm{~K}$, the $2 \mathrm{D}$ infrared spectra were similar. The characteristic peak of $v \mathrm{C}=\mathrm{C}, v \mathrm{C}=\mathrm{N}$ and $v_{\mathrm{C}-\mathrm{H}}$ at 1469,1558 and 2889-3025 $\mathrm{cm}^{-1}$ can be observed respectively, indicating that the bipyridine ligands was lost in the first two steps. At 623.81 
and $702.35 \mathrm{~K}$, the similar 2D infrared spectra were also found. The characteristic peak of $\mathrm{CO}_{2}, v_{\mathrm{C}=\mathrm{O}}$ and $v_{\mathrm{C}-\mathrm{H}}$ were observed at (2255-2347, $\left.669 \mathrm{~cm}^{-1}\right), \quad 1798$ and $(2893-3017) \mathrm{cm}^{-1}$ respectively, indicating the loss of carboxylic acid ligands. At $764.32 \mathrm{~K}$, there are only strong absorption peak of $\mathrm{CO}_{2}$ and $\mathrm{H}_{2} \mathrm{O}$ in the infrared spectrum. This indicates that the carboxylic acid ligands have been completely decomposed.

\subsection{Luminescence measurements}

The luminescent properties of solid-state complex 4 were studied at room temperature. The excitation and emission spectra of $\mathbf{4}$ are shown in Fig. 8a. The fluorescence decay curve was shown in Fig. 8b. From the excitation spectrum, we can see a wide absorption band, that is, the absorption peak of electron transition from ligand to metal ion. The strength of the absorption band proves that carboxylic acid ligand as an antenna can effectively sensitize lanthanide ions ${ }^{29}$.

For complex 4, the emission spectrum was scanned at the excitation wavelength of $330 \mathrm{~nm}$. It exhibits five emission peaks of $\mathrm{Eu}^{3+}:{ }^{5} D_{0} \rightarrow{ }^{7} F_{j}(j=0-5)(581,591,621,651,701 \mathrm{~nm})$, The emission at $621 \mathrm{~nm}$ was the electric dipole transition ${ }^{5} D_{0} \rightarrow{ }^{7} F_{2}$, while the emission at $591 \mathrm{~nm}$ was magnetic dipole transition ${ }^{5} D_{0} \rightarrow{ }^{7} F_{1}$. The highest peak ${ }^{5} D_{0} \rightarrow{ }^{7} F_{2}$ appears at $621 \mathrm{~nm}$, which is the reason why the complex presents strong red light under the UV lamp. Moreover, ${ }^{5} D_{0} \rightarrow{ }^{7} F_{2}$ is higher than ${ }^{5} D_{0} \rightarrow$ ${ }^{7} F_{1}$ indicated that the $\mathrm{Eu}^{3+}$ was located in an asymmetric coordination. According to the Judd-Ofelt theory, the ${ }^{5} D_{0} \rightarrow{ }^{7} F_{0}$ transition occurs only in asymmetric environments ${ }^{30}$. While, this transition was observed at $581 \mathrm{~nm}$ indicating that the $\mathrm{Eu}^{3+}$ is

(a)

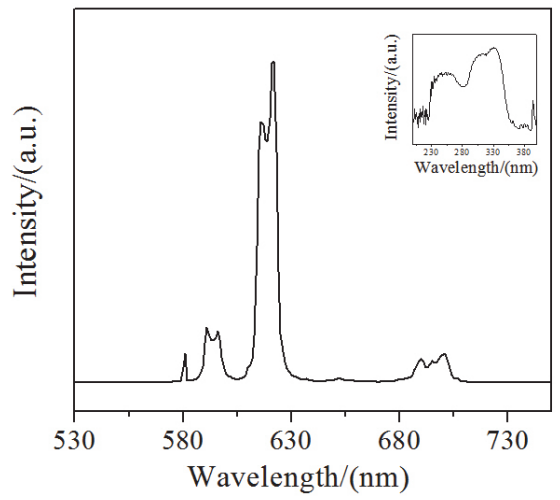

(b)

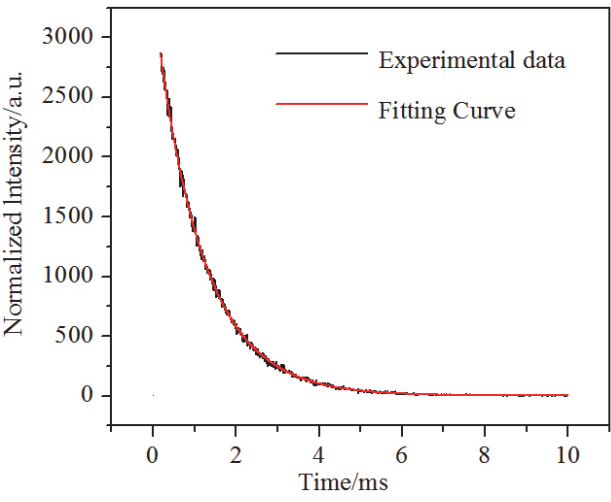

Fig. 8 (a) Emission and excitation spectrum of complex 4 in the solid state; (b) The fluorescence attenuation curves of the complex 4.

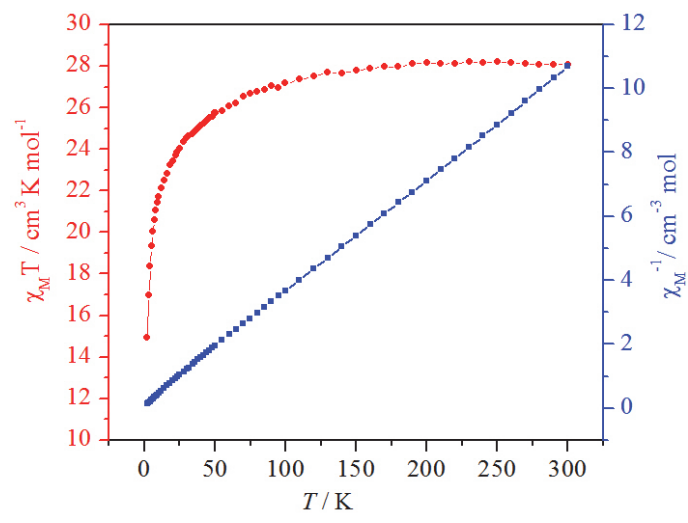

Fig. 9 Temperature dependence of the $\chi_{M} T$, and $1 / \chi_{M} T$ susceptibility for complex 6 in the range of 2-300 K.

at the asymmetric center. The lifetime $(\tau)$ of complex 4 can be calculated by the following equation:

$\left.\tau=\left(B_{1} \tau_{1}^{2}+B_{2} \tau_{2}^{2}\right)\right) /\left(B_{1} \tau_{1}+B_{2} \tau_{2}\right)$

$\tau_{1}$ and $\tau_{2}$ are the decay times and $B_{1}$ and $B_{2}$ are the fitting constants ${ }^{31}$. Finally, the lifetime $(\tau)$ of $\mathbf{4}$ is $1.15 \mathrm{~ms}$. Using the calculation formula proposed by Bunzli ${ }^{32}$ et al., the intrinsic quantum yield is calculated to be $45.1 \%$.

\subsection{Magnetic properties}

The magnetic properties of 6 in the temperature range of 2 $300 \mathrm{~K}$ were studied under the applied magnetic field of $1000 \mathrm{Oe}$. The $\chi_{M} T$ and $1 / \chi_{M} v s T$ of complex 6 are shown in Fig. 9.

For complex 6, the $\chi_{M} T$ value of $28.08 \mathrm{~cm}^{3} \cdot \mathrm{K} \cdot \mathrm{mol}^{-1}$ at room temperature is similar to the calculated value $28.34 \mathrm{~cm}^{3} \cdot \mathrm{K} \cdot \mathrm{mol}^{-1}$ of two isolated $\mathrm{Dy}^{3+}\left({ }^{6} H_{15 / 2}, J=15 / 2, g=4 / 3\right)$. With the decrease of temperature, the $\chi_{M} T$ value of $\mathbf{6}$ decreased slowly in the temperature range of $300-50 \mathrm{~K}$, but with the continuous decrease of temperature, the $\chi_{M} T$ value decreased sharply and reached the minimum value of $14.93 \mathrm{~cm}^{3} \cdot \mathrm{K} \cdot \mathrm{mol}^{-1}$ at $2 \mathrm{~K}$, which can be attributed to the antiferromagnetic interaction between $\mathrm{Dy}^{3+33}$.

\section{Conclusions}

In conclusion, six new ternary lanthanide complexes formulated as $\left[\operatorname{Ln}(2,4,6-T M B A)_{3}\left(5,5^{\prime}-\mathrm{DM}-2,2^{\prime} \text {-bipy }\right)\right]_{2}(\mathrm{Ln}=\mathrm{Pr}$ 1, Nd 2, Sm 3, Eu 4, Gd 5, Dy 6) have been synthesized under the solvothermal conditions. The structural analyses revealed that complexes 1-5 are isostructural and each center metal ion is nine-coordinated, while complex $\mathbf{6}$ is different with another structures and each center metal ion is eight-coordinated. Complexes 1-5 are packed into 2D sheet via the $\pi-\pi$ stacking interactions while complex 6 forms a 2D sheet through the $\pi-\pi$ stacking interactions and $\mathrm{C}-\mathrm{H} \cdots \mathrm{O}$ hydrogen bond interaction. Thermal analysis show that complexes 1-6 have similar thermal decomposition mechanisms and high thermal stability. The study of photoluminescence shows that solid complex $\mathbf{4}$ emits strong red light in the visible region, which indicates that 2,4,6-tmhbas are highly effective sensitizers and are expected to become luminescent materials. The magnetic properties of complex $\mathbf{6}$ show that there is antiferromagnetic interaction in the synthesized complex. 
Supplementary data: Crystallographic data for the structure reported in this paper are deposited in the Cambridge Crystallographic Data Center (CCDC 1906870(1); CCDC 1906869(2); CCDC 1906871(3); CCDC 1906867(4); CCDC 1906868(5); CCDC 1906865(6).)

Supporting Information: Thermal analysis curves of 1-6 are included. This information is available free of charge via the internet at http://www.whxb.pku.edu.cn.

\section{References}

(1) Janicki, R.; Mondry, A.; Starynowicz, P. Coordin. Chem. Rev. 2017, 340, 98. doi: 10.1016/j.ccr.2016.12.001

(2) Allendorf, M. D.; Bauer, C. A.; Bhakta, R. K.; Houk, R. J. Chem. Soc. Rev. 2009, 38 (5), 1330. doi: 10.1039/b802352m

(3) Ahmed, Z.; Iftikhar, K. Inorg. Chem. 2015, 54 (23), 11209. doi: 10.1021/acs.inorgchem.5b01630

(4) Bradberry, S. J.; Savyasachi, A. J.; Martinez-Calvo, M.; Gunnlaugsson, T. Coordin. Chem. Rev. 2014, 273-274, 226. doi: 10.1016/j.ccr.2014.03.023

(5) Bunzli, J. C.; Piguet, C. Chem. Soc. Rev. 2005, 34 (12), 1048. doi: $10.1039 / \mathrm{b} 406082 \mathrm{~m}$

(6) Hiller, M.; Krieg, S.; Ishikawa, N.; Enders, M. Inorg. Chem. 2017, 56 (24), 15285. doi: 10.1021/acs.inorgchem.7b02704

(7) Lin, P. H.; Burchell, T. J.; Clerac, R.; Murugesu, M. Angew. Chem. Int. Ed. Engl. 2008, 47 (46), 8848. doi: 10.1002/anie.200802966

(8) Reis, S. G.; Briganti, M.; Soriano, S.; Guedes, G. P.; Calancea, S.; Tiseanu, C. Inorg. Chem. 2016, 55 (22), 11676. doi: 10.1021/acs.inorgchem.6b01616

(9) Rinehart, J. D.; Long, J. R. Chem. Sci. 2011, 2 (11), 2078. doi: $10.1039 / \mathrm{c} 1 \mathrm{sc} 00513 \mathrm{~h}$

(10) Wang, G.; Song, T.; Fan, Y.; Xu, J.; Wang, M.; Wang, L. Inorg. Chem. Commun. 2010, 13 (1), 95. doi: 10.1016/j.inoche.2009.10.026

(11) Niu, Y.; Xu, Q.; Wang, Y.; Li, Z.; Lu, J.; Ma, P. Dalton Trans. 2018, 47 (29), 9677. doi: 10.1039/c8dt01243a

(12) Wang, W.; Wang, X.; Zhou, S.; Xu, X.; Du, J.; Zhang, L. Inorg. Chem. 2018, 57 (16), 10390. doi: 10.1021/acs.inorgchem.8b01556

(13) Li, Y. J.; Yan, B. Inorg. Chem. 2009, 48 (17), 8276. doi: $10.1021 /$ ic $900971 \mathrm{~h}$

(14) Heffern, M. C.; Matosziuk, L. M.; Meade, T. J. Chem. Rev. 2014, 114 (8), 4496. doi: 10.1021/cr400477t

(15) Bünzli, J. C. G. J. Lumin. 2016, 170, 866. doi: 10.1016/j.jlumin.2015.07.033
(16) Zhao, Q. Q.; Zhu, M. M.; Ren, N.; Zhang, J. J. J. Mol. Struct. 2017, 1149, 171. doi: 10.1016/j.molstruc.2017.07.080

(17) Monteiro, J. H. S. K.; Sigoli, F. A.; de Bettencourt-Dias, A. Can. J. Chem. 2018, 96 (9), 859. doi: 10.1139/cjc-2017-0436

(18) Jin, C. W.; Wang, Y.; Ren, N.; Geng, L. N.; Zhang, J. J. J. Chem. Thermodyn. 2016, 103, 181. doi: 10.1016/j.jct.2016.08.011

(19) Wu, J.; Li, H.; Ren, N.; Zhang, J.; Wang, S. J. Rare Earths 2016, 34 (11), 1083. doi: 10.1016/s1002-0721(16)60138-2

(20) Xia, C. K.; Sun, W.; Min, Y. Y.; Yang, K.; Wu, Y. L. Polyhedron 2018, 141, 377. doi: 10.1016/j.poly.2017.11.011

(21) Utochnikova, V. V.; Grishko, A.; Vashchenko, A.; Goloveshkin, A.; Averin, A.; Kuzmina, N. Eur. J. Inorg. Chem. 2017, 2017 (48), 5635. doi: 10.1002/ejic.201700896

(22) He, S. M.; Sun, S. J.; Zheng, J. R.; Zhang, J. J. Spectrochim. Acta A Mol. Biomol. Spectrosc. 2014, 123, 211. doi: 10.1016/j.saa.2013.12.023

(23) Carter, K. P.; Pope, S. J. A.; Cahill, C. L. CrystEngComm 2014, 16 (10), 1873. doi: 10.1039/c3ce42267d

(24) Zapała, L.; Kosińska, M.; Woźnicka, E.; Byczyński, Ł.; Zapała, W.; Kalembkiewicz, J. J. Anal. Appl. Pyrol. 2017, 123, 1. doi: 10.1016/j.jaap.2017.01.010

(25) Gao, H. L.; Huang, S. X.; Zhou, X. P.; Liu, Z.; Cui, J. Z. Dalton Trans. 2018, 47 (10), 3503. doi: 10.1039/c8dt00063h

(26) Kariem, M.; Yawer, M.; Kumar, M.; Nawaz Sheikh, H.; Sood, P.; Kolekar, S. S. J. Solid. State. Chem. 2017, 255, 61. doi: 10.1016/j.jssc.2017.08.001

(27) Shen, P. P.; Zhu, M. M.; Ren, N.; Zhang, J. J.; Wang, S. P. Appl. Organomet. Chem. 2017, 31 (12), e3886, doi: 10.1002/aoc.3886

(28) Xie, H.; Lu, G. J. Rare Earths 2013, 31 (6), 639. doi: 10.1016/s1002-0721(12)60334-2

(29) Zhao, Y. F.; Chu, H. B.; Bai, F.; Gao, D. Q.; Zhang, H. X.; Zhou, Y. S. J. Organomet. Chem. 2012, 716, 167. doi: 10.1016/j.jorganchem.2012.06.031

(30) Shen, C. Q.; Yan, T. L.; Wang, Y. T.; Ye, Z. J.; Xu, C. J.; Zhou, W. J. J. Lumin. 2017, 184, 48. doi: 10.1016/j.jlumin.2016.12.018

(31) Zhu, M. M.; Ren, N.; Zhang, J. J. Inorg. Chim. Acta 2018, 480, 140. doi: 10.1016/j.ica.2018.05.022

(32) Bünzli, J. C. G.; Chauvin, A. S.; Kim, H. K.; Deiters, E.; Eliseeva, S. V. Coordin. Chem. Rev. 2010, 254 (21-22), 2623. doi: 10.1016/j.ccr.2010.04.002

(33) Wei, X. H.; Yang, L. Y.; Liao, S. Y.; Zhang, M.; Tian, J. L.; Du, P. Y. Dalton Trans. 2014, 43 (15), 5793. doi: 10.1039/c3dt53112k 